\title{
Changes in serum proteins after endotoxin administration in healthy and choline- treated calves
}

\author{
Z. Yilmaz ${ }^{1 *}$, O. Eralp Inan², M. Kocaturk' ${ }^{1}$ A. T. Baykal ${ }^{3}$, O. Hacariz ${ }^{4}$, I. Hatipoglu ${ }^{5}$ A. Tvarijonaviciute ${ }^{6,8}$, M. Cansev ${ }^{7}$, \\ J. Ceron ${ }^{8}$ and I. H. Ulus ${ }^{9}$
}

\begin{abstract}
Background: This study aimed to investigate the possible serum protein changes after endotoxin administration in healthy and choline-treated calves using proteomics. These results are expected to contribute to the understanding of the pathophysiological mechanisms of endotoxemia and the beneficial effect of choline administration in this clinical situation.

Methods: Healthy-calves $(n=20)$ were divided into 4 groups: Control, Choline treated $(C)$, Lipopolysaccharide administered (LPS), and LPS + C. Control calves received $0.9 \% \mathrm{NaCl}$ injection. Calves in C and LPS + C groups received choline chloride (1 mg/kg/iv). Endotoxin (LPS) was injected ( $2 \mu \mathrm{g} / \mathrm{kg} / \mathrm{iv})$ to the calves in LPS and LPS + C groups. Serum samples were collected before and after the treatments. Differentially expressed proteins ( $>1.5$ fold-change relative to controls) were identified by LC-MS/MS.

Results: After LPS administration, 14 proteins increased, and 13 proteins decreased within $48 \mathrm{~h}$ as compared to controls. In the LPS group, there were significant increases in serum levels of ragulator complex protein (189-fold) and galectin-3-binding protein (10-fold), but transcription factor Maff and corticosteroid binding globulin were down regulated ( $\geq 5$ fold). As compared with the LPS group, in LPS $+C$ group, fibrinogen gamma-B-chain and antithrombin were up-regulated, while hemopexin and histone $\mathrm{H} 4$ were down-regulated. Choline treatment attenuated actin alpha cardiac muscle-1 overexpression after LPS.

Conclusions: LPS administration produces changes in serum proteins associated with lipid metabolism, immune and inflammatory response, protein binding/transport, cell adhesion, venous thrombosis, cardiac contractility and blood coagulation. The administration of choline is associated with changes in proteins which can be related with its beneficial effect in this clinical situation.
\end{abstract}

Keywords: Calves, Choline, Endotoxemia, Proteomic, Sepsis

\section{Background}

Endotoxemia is defined as the presence of endotoxins in blood. This situation can occur by Gram-negative bacterial infections which liberate endotoxin (lipopolysaccharides; LPS) during rapid growth. This results in the fact that Gram-negative sepsis is associated with high mortality rates, despite comprehensive treatment in intensive care patients [1]. Studies are underway with

\footnotetext{
* Correspondence: zyilmaz@uludag.edu.tr

${ }^{1}$ Department of Internal Medicine, Faculty of Veterinary Medicine, Uludag University, 16059 Bursa, Turkey

Full list of author information is available at the end of the article
}

regards to understanding the complex pathophysiological mechanism of endotoxemia, describing criteria for early diagnosis and developing new treatment approaches in order to decrease mortality [2, 3].

Intravenous choline administration show beneficial effects in the treatment of endotoxemia [4-7] in various species such as dogs and rats. Beneficial effects of intravenous choline treatment are reported in association with the activation of the efferent vagus nerve-based cholinergic anti-inflammatory pathway by the increase in nicotinic cholinergic neuro-transmission $[5,8]$ following enhanced acetylcholine release by choline [9]. However 
the possible changes in serum proteins that choline treatment can produce has not been studied.

Proteomics analysis allows the simultaneous analysis of thousands of proteins in a sample. This could facilitate the identification of new biomarkers of use for diagnosis and prognosis of sepsis/endotoxemia [10, 11]. Thus, proteomic analyses are a growing trend in human [12] and veterinary medicine [13]. In particular proteomic studies allow identifying new proteins that change in endotoxemia, and by knowing the function of these new proteins, new mechanisms involved in endotoxemia could be elucidated and therefore increase the knowledge about its pathophysiology [14].

In the light of our previous findings [4-7], we hypothesize that the beneficial effect of choline administration in endotoxemic patients could be mediated by changes in concentrations of selected serum proteins. Therefore the objective of this study was to evaluate the possible changes that can occur in serum proteins, by a proteomic analysis, after endotoxin administration in healthy and choline-treated calves.

\section{Methods}

\section{Experimental set up}

Healthy Holstein calves (4 weeks of age; $40 \mathrm{~kg}$ mean weight; $n=20$ ) were used in the present study. Their health status was evaluated by clinical, haematological and serum biochemical analyses. Calves were negative for bovine herpes virus, bovine leucosis virus, brucellosis, bovine viral diarrhea, foot and mouth disease, infectious bovine rhinotracheitis, paratuberculosis, and tuberculosis when tested by commercial ELISA kits (IDVet Diagnostics, Grabels, France).

Calves were randomized equally into 4 groups: Control, Choline treated $(\mathrm{C})$, Lipopolysaccharide administered (LPS), and LPS + C. Calves in the Control group were injected with $0.9 \% \mathrm{NaCl}$ (saline; $5 \mathrm{ml}$, i.v.) twice at an interval of $5 \mathrm{~min}$ while those in $\mathrm{C}$ group received choline chloride $(1 \mathrm{mg} / \mathrm{kg}$, dissolved in $5 \mathrm{ml}$ of saline, i.v., once), 5 min after $0.9 \% \mathrm{NaCl}$ administration (5 ml, i.v.). In the LPS group, endotoxin (LPS) was injected $(2 \mu \mathrm{g} / \mathrm{kg}$, dissolved in $5 \mathrm{ml}$ of normal saline, i.v., once) to the calves, followed 5 min later by intravenous injection of normal saline. In LPS $+C$ group, endotoxin injection was followed $5 \mathrm{~min}$ later by choline chloride injection at the doses described in the LPS and C groups, respectively $[15,16]$.

\section{Clinical data}

Routine clinical examinations were performed before (baseline) and 0.5-48 h after the treatments. A scoring system adapted from a previous paper [17] was used to evaluate clinical status in the study. Each parameter was scored by minimum 0 point (means normal) to maximum 6 points (means severely affected).

\section{Serum proteomic analysis}

In order to analyse differences in protein expression in the course of the study, three serum samples at each time point for each treatment were obtained and the protein profiles of the serum samples were analysed by LC-MS/MS method [18-20]. Albumin depletion from serum samples was done with albumin depletion spin columns (Pierce, Thermo Scientific). IgGs from the albumin-depleted serum samples were also depleted with an Albumin/IgG Removal Kit (Pierce, Thermo scientific). The remaining serum proteins (at same concentration for all samples) were extracted and enzymatically digested into peptides, and the resulting peptides were subjected to the nanoUPLC-ESI-qTOF-MS system (nanoultra-performance LC and ESI quadrupole TOF MS) (Waters) with the application of data independent acquisition method also known as the $\mathrm{MS}^{\mathrm{E}}$ as previously described in detail [20]. Minimum 3 technical replicates for each sample were used for the analysis. The proteomic data was searched against a reviewed database [including protein sequences of Bos taurus and an internal standard (enolase, Saccharomyces cerevisiae; \#P00924), obtained from UniProt (htpp://www.uniprot.org)] with previously described in silico parameters [19]. Quantitative differences of proteins at different time points were calculated using Progenesis LC-MS software V4.0 (Nonlinear Dynamics) [20].

\section{Chemicals}

Choline chloride and endotoxin (E. coli lipopolysaccharide, LPS, serotype 055:B5) were purchased from Sigma Chemical Co. (St. Louis, Missouri, USA).

\section{Statistical analysis}

Results were expressed as mean \pm SEM. Data were evaluated by one-way analysis of variance by repeated measures, followed by Tukey test for pairwise comparisons. Clinical scores were compared by a non-parametric test (Friedman Repeated Measure ANOVA on Ranks). $P$ values less than 0.05 were considered significant.

\section{Results \\ Clinical data}

Clinical findings are presented as Additional file 1 (Fig. 1). Briefly, choline induced a decrease in heart and respiratory rates compared with the control animals. LPS administration increased body temperature and heart and respiratory rates as compared to their baselines. The severities of these changes in LPS $+C$ treatment were lower $(p<0.01)$ than those of calves treated with LPS. 
A
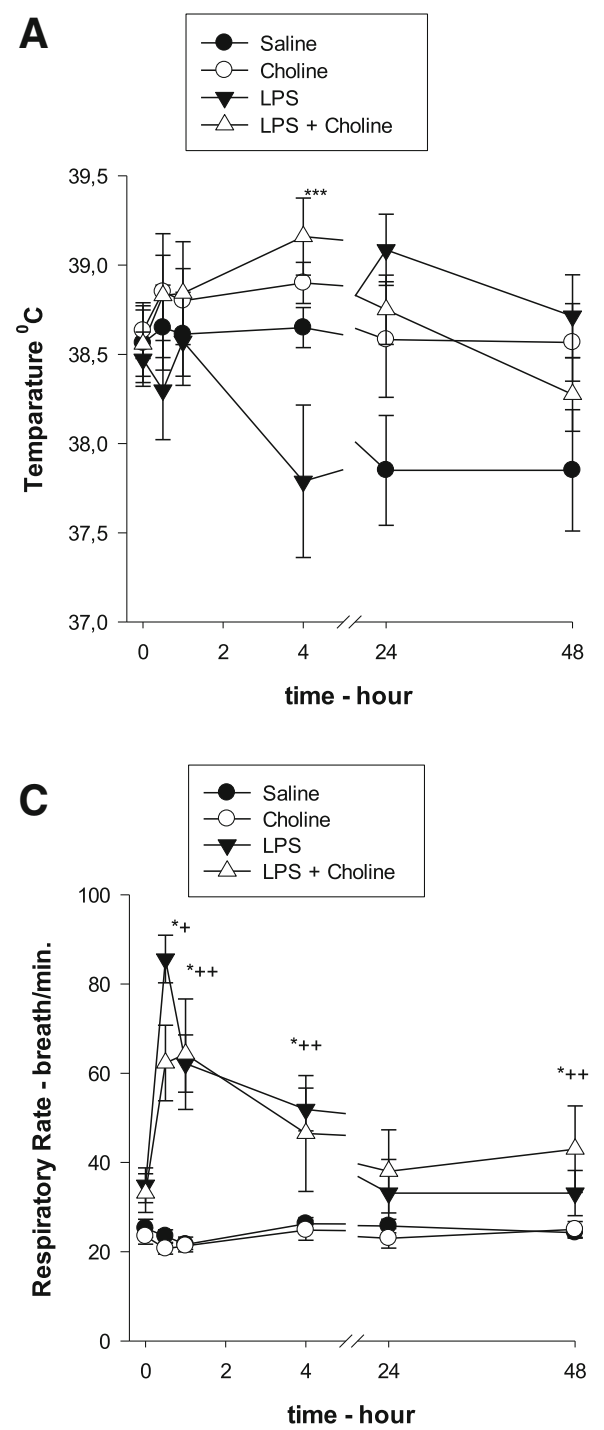

B
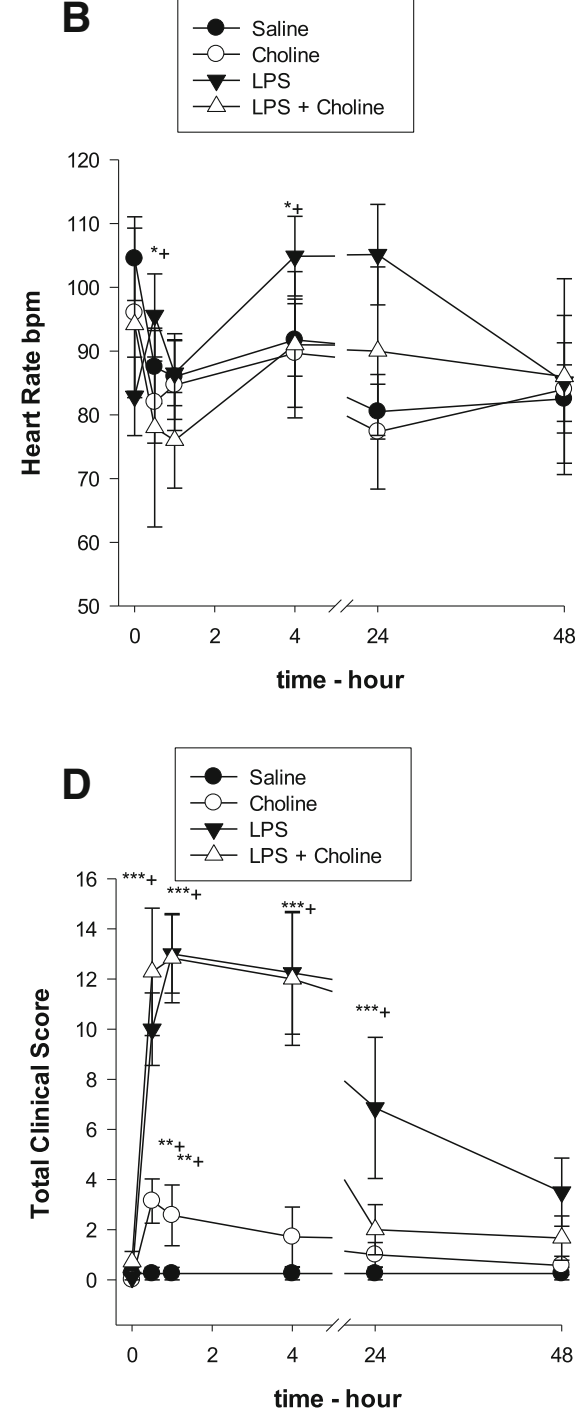

Fig. 1 Clinical parameters (a, temperature; $\mathbf{b}-\mathbf{c}$, heart and respiratory rates; and $\mathbf{d}$, total clinical score) in saline, choline, LPS and LPS + choline groups. Calves were injected i.v. once with saline $(5 \mathrm{ml})$ or saline containing choline chloride $(1 \mathrm{mg} / \mathrm{kg})$. Five minutes after the first i.v. treatment, calves received endotoxin (LPS, $2 \mu \mathrm{g} / \mathrm{kg})$ in $5 \mathrm{ml}$ normal saline. Measurements were performed immediately before first i.v. treatment $(0 \mathrm{~h})$ and $1-48 \mathrm{~h}$ after saline, choline, LPS or LPS + choline treatments. Each point represents to Mean \pm SEM of six determinations. ${ }^{*} p<0.05,{ }^{* *} p<0.001,{ }^{* * *} p<0.001$ as compared to baseline $+p<0.05,++p<0.01$ as compared to saline group

Two calves died at 4 and $24 \mathrm{~h}$ after LPS and one at $48 \mathrm{~h}$ after LPS $+\mathrm{C}$. Calves in control and choline groups survived until the end of the study.

\section{Serum proteins}

Protein expression differences among experimental groups at different time points (30 min, 1, 4 and $48 \mathrm{~h}$ ) are shown in Table 1. Details including numerical values for the quantitative analysis obtained from the Progenesis LC-MS software are shown in Additional file 1.

A total of 76 proteins were identified across the serum samples by the proteomic analysis. After LPS administration, 14 proteins increased, whereas 13 proteins decreased within $48 \mathrm{~h}$ as compared to controls (Table 1). In LPS group, there was a dramatic increase (189 fold, at $24 \mathrm{~h}$ ) in ragulator complex protein LAMTOR2 which was followed by other proteins showing changes ranging from 6 to 13 fold such as negative elongation factor $E$ (at $4 \mathrm{~h}$ ), galectin-3 binding protein (Gal-3BP), argininosuccinate lyase and membrane primary amine-oxidase (at $48 \mathrm{~h}$ ). Following LPS administration, moderate decreases $(<5$ fold changes) were observed in some proteins such as serpin A3-4 (at $30 \mathrm{~min}$.), vitamin D binding protein (VDBP), inter alpha trypsin inhibitor heavy chain $\mathrm{H} 3$ (ITIH, at $4 \mathrm{~h}$ ), apolipoprotein A IV (Apo-AIV), alpha-1B glycoprotein and serotransferrin 
Table 1 Protein expression differences among experimental groups at different time points (30 min, $1 \mathrm{~h}, 4 \mathrm{~h}$ and $48 \mathrm{~h}$ )

LPS_Choline P02081; Hemoglobin fetal subunit $\quad$ A217N1; Serpin A3 5/1.44

Q9TTE1; Serpin A3 1/209

beta/1.52

Q9TTK6; Membrane primary amine

Q80E01; Glutaredoxin 1/2.21

Q9QAQ7; Non structural protein of

oxidase/Infinity

Q3SZJ0; Argininosuccinate lyase/1.8

P01966; Hemoglobin subunit alpha/1.50

Q17QL1; Glucosamine 6 phosphate

P02676; Fibrinogen beta chain/3.83 P19034; Apolipoprotein C II/2.82

isomerase $2 / 2.96$

A217N1; Serpin A3 5/1.44 Q9MYP6; beta hydroxysteroid dehydrogenase

Q3T0Z5; Leukocyte receptor cluster

Q3ZC07*; Actin alpha cardiac muscle 1/15.21

Q9TTE1; Serpin A3 1/1.74

Q32L76; Serum amyloid A 4 protein/1.70 Q1JQ97; Bardet Biedl syndrome 4 protein

A217N3; Serpin A3 7/1.44

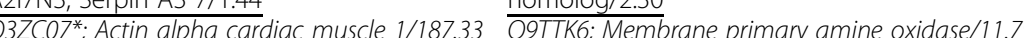

POCH28*. Polyubiquitin C 1.59 Membrane primary amine

P81644; Apolipoprotein A II/1.45

P12799; Fibrinogen gamma B chain/8.44

Q32L76; Serum amyloid A 4 protein/2.20

Q5E9E3; Complement C19 subcomponent

P02676; Fibrinogen beta chain/64.53 subunit A/3.01

P34955; Alpha 1 antiproteinase/1.60

A217N0; Serpin A3 4/1.47

P41361; Antithrombin 1II/2.67

P00735; Prothrombin/2.287

P12799; Fibrinogen gamma

Bchain/5.92

P28800: Alpha 2 antiplasmin/1.43

P80012; von Willebrand factor Fragment/2.98

LPS P17697; Clusterin/1.43

Q0V898; Negative elongation factor E/1.68

A217N2; Serpin A3 6/1.64

P81644; Apolipoprotein A II/1.62

Q9TTK6; Membrane primary amine

OXidase/7.17

19035; Apolipoprotein C III/2.80

Q5E9E3; Complement C1q subcomponent

subunit $A / 2.66$

O46406; Primary amine oxidase lung

isozyme/3.74

28901: 6-p-2-k-f-2-6-b-f/infinity

P01966; Hemoglobin subunit alpha/1.81

P01044; Kininogen 1/2.13

P02081; Hemoglobin fetal subunit beta/1.55

A7E3W2; Galectin 3 binding protein/13.09

P41356; Fusion glycoprotein F0/1.82

O62830-2; Isoform Beta 2 of Protein

phosphatase 1B/6.78

P80109; P-g-s-p-d/1.50

Q5E9F5; Transgelin 2/2.90

P22226: Cathelicidin 1/13.17

$\frac{\text { Q7SIH1; Alpha } 2 \text { macroglobulin/1.41 }}{\text { A217M9; Serpin A3 2/9.68 }}$

Q3T132; Ragulator complex protein

LAMTOR2/189.5

P27M9, SerpA A3 2/9.68

P00924; ENOI YEAST Enolase 1/1.46

Q9QAQ7; Bovine coronavirus strain OK 0514

GN $4 a / 4.93$

in

Q0V898; Negative elongation factor E/10.86

Q28901;6-p-2-k-f-2-6-b-f/Infinity

Q37C07, Actin alpha cardiac muscle 1/25.52

P80109; Phosphatidylinositol glycan specific

phospholipase D/3.11

O02659; Mannose binding protein C/5.76

POCH28*; Polyubiquitin C/4.09

A8YXX7: Trefoil factor $3 / 4.93$

Q2TBS3; Uncharacterized protein C20orf79

$\frac{\text { homolog/4.76 }}{\text { Q96629; }}$

Q96629; Adenain/2.23

P19034; Apolipoprotein C II/4.21

Q1JP73; UPF0553 protein C9orf64 homolog/12.57

Q9TTK6-2; Isoform 2 of Membrane

primary amine oxidase/2.30

Q1.JP73: UPF0553 protein C90rf64

homolog/1.95

Q56K14; 60S acidic ribosomal protein P1/Infinity

Q3SZV7; Hemopexin/2.10

Q1JQ97; Bardet Biedl syndrome 4

protein homolog/1.48

Q56K14;60S acidic ribosomal protein P1/Infinity

Q96629; Adenain/1.74

Q2KITO; Protein HP 20 homolog/1.93

P62803; Histone H4/11.67 
Table 1 Protein expression differences among experimental groups at different time points (30 min, $1 \mathrm{~h}, 4 \mathrm{~h}$ and $48 \mathrm{~h}$ ) (Continued)

Choline

$$
\begin{aligned}
& \text { O46406; Primary amine oxidase lung } \\
& \text { isozyme/1.74 } \\
& \text { Q28901; 6-p-2-k-f-2-6-b-f/Infinity } \\
& \text { Q2M2T2; Uncharacterized protein } \\
& \text { C190rf71/1.78 } \\
& \text { A2I7N3; Serpin A3 7/1.56 } \\
& \text { Q17QL 1; Glucosamine } 6 \text { phosphate } \\
& \text { isomerase 2/1.48 }
\end{aligned}
$$

\begin{tabular}{|c|c|c|c|}
\hline & P80012; von Willebrand factor Fragment/2.08 & A217N0; Serpin A3 4/1.60 & P21752; Thymosin beta 10/1.45 \\
\hline & $\begin{array}{l}\text { Q3SZKO; Solute carrier family } 25 \text { member 34/ } \\
1.72\end{array}$ & $\begin{array}{l}\text { Q2TBS3; Uncharacterized protein } \\
\text { C20orf79/2.01 }\end{array}$ & $\begin{array}{l}\text { Q3T132; Ragulator complex protein } \\
\text { LAMTOR2/2.04 }\end{array}$ \\
\hline & $\begin{array}{l}\text { Q05204; Lysosome associated membrane } \\
\text { glycoprotein 1/2.34 }\end{array}$ & & $\frac{\text { P01044-2*; Isoform LMW of Kininogen }}{1 / 2.87}$ \\
\hline & & $\begin{array}{l}\text { Q9TTK6-2; Isoform } 2 \text { of Membrane primary } \\
\text { amine oxidase/2.82 }\end{array}$ & \\
\hline & Q80E01; Glutaredoxin 1/3.37 & & $\underline{\text { Q58CQ9; Pantetheinase/1.58 }}$ \\
\hline & $\frac{\text { Q05204; Lysosome associated membrane }}{\text { glycoprotein 1/10.89 }}$ & Q3MHN5; Vitamin D binding protein/1.48 & \\
\hline & & & Q96629; Adenain/1.69 \\
\hline & Q2KIU3; Protein HP 25 homolog 2/1.70 & $\begin{array}{l}\text { P56652; Inter alpha trypsin inhibitor heavy chain } \\
\text { H3/1.58 }\end{array}$ & \\
\hline & P02081; Hemoglobin fetal subunit beta/1.72 & Q29443; Serotransferrin/1.57 & $\begin{array}{l}\text { P01044-2*; Isoform LMW of Kininogen } \\
\text { 1/1.62 }\end{array}$ \\
\hline & & Q32PJ2; Apolipoprotein A IV/1.45 & Q58CQ9; Pantetheinase/1.84 \\
\hline & & $\underline{\text { A217N2; Serpin A3 6/4.57 }}$ & P21752; Thymosin beta 10/1.46 \\
\hline & & $\underline{\text { Q2KJF1; Alpha 1B glycoprotein/1.46 }}$ & Q9MYP6;17 beta hydroxysteroid \\
\hline & & P01966; Hemoglobin subunit alpha/1.63 & aenyarogenase $14 / 2.24$ \\
\hline & & P02070; Hemoglobin subunit beta/1.98 & \\
\hline & & A7YY73; Transcription factor MafF/5.00 & \\
\hline & & $\frac{\text { E1BF81; Corticosteroid binding }}{\text { globulin/5.27 }}$ & \\
\hline Control & Choline & LPS & LPS_Choline \\
\hline
\end{tabular}

Control

This table shows the identified proteins with highest mean condition (left) and lowest mean condition (bottom) among experimental groups at different time points at statistically significant level $(P<0.05)$. Relative abundance levels of the proteins with highest mean condition, compared to the proteins with lowest mean condition, are indicated after the slash ( $)$. Time points are indicated with underline, italic and italic + underline, for

$1 \mathrm{~h}, 4 \mathrm{~h}$ and $48 \mathrm{~h}$ time points, respectively. Asterisk (*) indicates the proteins, of which, isoforms are detectable (see Additional file for the accession numbers of the isoforms). Abbreviations; c. e.: conjugating enzyme, $6-\mathrm{p}-2-\mathrm{k}-\mathrm{f}-\mathrm{f}$ $1 \mathrm{~h}, 4 \mathrm{~h}$ and $48 \mathrm{~h}$ time points, respectively. Asterisk (*) indicates the proteins, of which, isoforms are detectable (see Additional file for the accession numbers of the isoforms). Abbreviations; C. e.: conjugating enzy
2-6-b-f; 6 phosphofructo 2 kinase fructose 26 bisphosphatase 3 Fragment, $\mathrm{m}-1-\mathrm{h}$; member 1 homolog, U-p-C19orf71-h; Uncharacterized protein C19orf71 homolog, P-g-s-p-d; Phosphatidylinositol glycan specific

phospholipase D

\section{A5PJC4; Ubiquitin ISG15 C. e. \\ E2 L6/1.45 \\ Q80E01: Glutaredoxin $1 / 1.40$ \\ QOVCI2; Syntaxin 19/3.81}

Q0V898; Negative elongation

factor $E / 2.4$

Q1/814, 605 acidic ribosomal protein

P34955; Alpha 1 antiproteinase/1.47

A217N2; Serpin A3 6/1.72

Q3SZJ0; Argininosuccinate lyase/1.41

Q17QL1; Glucosamine 6 phosphate isomerase 2/8.44

01044-2*; Isoform LMW of Kininogen

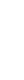


(at $48 \mathrm{~h}$ ). In addition more prominent decreases ( $\geq 5$ fold changes, at $48 \mathrm{~h}$ ) were observed in transcription factor MafF and corticosteroid binding globulin (CBG).

When compared with LPS group, in LPS $+\mathrm{C}$ group, glucosamine-6-phosphate isomerase-2, membrane primary amine oxidase, fibrinogen gamma $\mathrm{B}$ chain, antithrombin and prothrombin were markedly up-regulated, while isoform 2 of membrane primary amine oxidase, hemopexin and histone- $\mathrm{H} 4$ were markedly down-regulated. Actin alpha cardiac muscle-1 expression increased at 1-48 h (15-187 fold) in LPS and LPS + C groups, as compared to controls. The magnitude of increase in actin alpha cardiac muscle- 1 was lower at $48 \mathrm{~h}$ in LPS $+\mathrm{C}$ group than that of LPS group. As compared to controls, following choline administration, a number of proteins (primary amine oxidase, serpin A3-7 and glucosamine6-phosphate isomerase-2) were up-regulated while others (lysosome associated membrane glycoprotein-1 and glutaredoxin-1) were more down-regulated at different time points of the study.

\section{Discussion}

In this study, an experimental model consisting in the induction of endotoxemia by LPS administration in calves was chosen, because calves are very sensitive to LPS. Therefore is expected that the changes associated with LPS as well as its treatment will be easier to detect than with other animal models. The clinical changes occurred after LPS treatment in our experimental model in calves showed similarities with the results of experimental human [21] and animal studies of sepsis/endotoxemia $[4-7,15-17]$.

To our knowledge, our study describes for the first time 14 proteins that are up-regulated, and 13 proteins that are down-regulated in endotoxemia in calves. The roles of some of these altered proteins are highlighted below.

One of the proteins that were dramatically up-regulated was ragulator complex protein LAMTOR2. This protein is known to be involved in amino acid sensing and activation of mTORC1 [22], a signalling complex promoting cell growth in response to growth factors, energy levels, and amino acids. A previous study reported that severe immunological defects affecting the immunity in human primary immunodeficiency syndrome was associated with reduced levels of LAMTOR2 [22]. Hence, the elevated serum levels of ragulator complex in our study may be associated with host's response by increasing macrophage activity and enhancing adaptive immunity in response to LPS. Thus, ragulator complex may represent a new early diagnostic marker for the detection of inflammation in calves, due to its dramatic overexpression shortly after LPS treatment.
Another protein, which significantly increased in calves after LPS administration, was Gal-3BP. This protein has stimulatory activity on lymphokine-activated and natural killer cells, and also stimulates the secretion of many cytokines and interleukins in peripheral blood mononuclear cells that all play a contributory role in inflammation [23]. In this study, up-regulated expression of Gal-3BP may be associated with limiting an on-going inflammation in response to LPS, because of its immune modulatory activity [23]. In addition, overexpressed Gal-3BP may be considered as a host response to neutralize harmful effects of Galectin-3 which is released from LPSstimulated cells to produce heightened levels of inflammatory mediators, resulting in further tissue damage and, ultimately, organ failure, characteristics of sepsis. On the other hand, Gal-3BP has a critical role in the development of venous thrombosis [24] and to increase the survival of cancer cells in the bloodstream [25], indicating that probably is involved in the pathophysiological responses of different pathological conditions.

Transcription factor MafF and CBG are associated with interleukin regulation [26], and have a protective effect in situations of cell stress, coagulation cascade activation and severe illness [27]. A possible reason for the down regulations of these proteins found in our study may be excessive use of them to neutralize detrimental effects of LPS during acute phase reaction.

Proteases from LPS-activated leukocytes can trigger tissue and organ damage and enhance the nonspecific proteolysis of plasma clotting factors in patients with severe sepsis. One example is the leukocyte elastase that is involved in the progress of complications in patients with sepsis [28]. In the present study, down regulation of ITIH-H3 in calves with LPS was most probably due to extended secretion of elastase [28], thereby this protein may be a part of the regulatory system that controls acute inflammation [29] in calves. Similar to our finding, circulating ITIH protein level was found lower in patients with severe sepsis than in healthy volunteers [28].

Confirming our previous findings in dogs and rats [4-7], we found in the present study that choline treatment improved the clinical signs associated to LPS. Further studies including larger number of calves are needed to evaluate if choline treatment could reduce mortality rate in this clinical condition. Endotoxemia studies in dogs showed that these beneficial effects of choline treatment might be related with inhibition of TNF- $\alpha$ synthesis [4], prevention of hepato-renal injury [4], and attenuation of the changes of serum butrylcholinesterase and paraoxonase- 1 activities [30].

Most of the down-regulated proteins after choline treatment such as kininogen-1, prothrombin, and ragulator complex are involved in coagulation and the development of DIC. Therefore the decrease of these proteins 
could be associated with the preventive effects of choline treatment on the development of coagulopathy, as described previously in dogs [7]. In addition the downregulation of histones after choline treatment would be related with the protective effect of choline. Histone proteins, mainly the histones- $\mathrm{H} 3$ and $\mathrm{H} 4$, have been reported to exhibit cytotoxicity when released to the extracellular fluid in response to severe stress or inflammatory challenges like sepsis and to mediate excessive and overwhelming cell damage and death [31]. Hemopexin $(\mathrm{Hx})$ is mainly expressed as an APP from liver after inflammation [32]. In this study, Hx overexpression may be related with its antioxidant role [32] to facilitate tissue repair in response to LPS [33]. Choline treatment decreased $\mathrm{Hx}$ overexpression in calves with LPS, probably related with the reduction in body's antioxidant needs $[32,34]$ due to the reduction in tissue damage produced by choline [3].

The increase found in SAA4 after choline administration could be related with the protective effect that has been described for SAA by inhibiting TNF and LPS as well as platelet aggregation [35]. In addition a correlation between SAA4 and cholinesterase has been found, therefore a link between SAA4 response and choline administration could be hypothesized [36].

Choline treatment attenuated overexpression of contractile protein actin alpha cardiac muscle-1 (ACTC1) at $48 \mathrm{~h}$ after LPS, indicating a protective effect of choline treatment on sepsis-induced myocardial dysfunction (SIMD). SIMD is a well-recognized manifestation of organ dysfunction in patient with sepsis [37] and calves with endotoxemia [38]. LPS-induced overexpression of ACTC1 may contribute to myocardial dysfunction during endotoxemia [39], most probably due to impaired sarcomere integrity [40]. The observed overexpression of ACTC1 may be due to decreased thymosin beta-10 expression since thymosin beta-10 plays an important role in the organization of the cytoskeleton by binding to and sequestering actin monomers resulting with an inhibition in actin polymerization [41].

\section{Conclusion}

Although this is a pilot study made with a small sample size and therefore the results should be taken with caution. It could be concluded that based on our experimental model, following LPS administration, there are changes in selected serum proteins which are associated with various biological processes such as lipid metabolism, immune and inflammatory response, protein binding and transport, cell adhesion, venous thrombosis, cardiac contraction and blood coagulation. In addition choline administration is associated with changes in serum concentrations of selected serum proteins that would be related with its beneficial effect in this clinical situation. These findings would reinforce the effectiveness of choline administration in the treatment of endotoxemia. However further studies are needed to confirm our results due to small sample size of this study, and in addition it would be interesting to evaluate the effectiveness of choline treatment in combination with other drugs such as steroidal or non-steroidal anti-inflammatory drugs.

\section{Additional file}

Additional file 1: Clinical parameters (temperature, heart and respiratory rates, and total clinical score) in all groups. (XLSX $109 \mathrm{~kb}$ )

Acknowledgement

This study (TOVAG-1110026) was supported by The Scientific and Technological Research Council of Turkey (TUBITAK).

Availability of data and materials

Additional file can be associated with this article.

If the reader requires more information to help with interpretation of the results, please contact the corresponding author.

\section{Authors' contributions \\ ZY Research idea, study design, write up, corresponding author. OEl Experimental procedures. MK Experimental procedures. ATB Proteomic analysis and its validation for calves. $\mathrm{OH}$ Proteomic analysis and expression of proteomic results in a Table. IH Proteomic analysis. AT Biochemical analysis, and review. MC free choline measurements. JC Review and write up. IHU Statistical analysis, grammatical correction, and adviser for the study. All authors read and approved the final manuscript.}

\section{Competing interests}

None of the authors has any financial or personal relationships that could inappropriately influence or bias the content of the paper.

\section{Consent for publication}

Not applicable.

\section{Ethics approval and consent to participate}

The experimental protocol was approved by the Animal Care and Use Committee of Uludag University (Bursa, Turkey; Approval ID: 2010-09/03).

\section{Author details}

${ }^{1}$ Department of Internal Medicine, Faculty of Veterinary Medicine, Uludag University, 16059 Bursa, Turkey. ${ }^{2}$ Medical and Surgical Experimental Animal Practice and Research Center, Eskisehir Osmangazi University, 26480 Eskisehir, Turkey. ${ }^{3}$ Department of Medical Biochemistry, Acibadem University School of Medicine, Istanbul, Turkey. ${ }^{4}$ TÜBITAK Marmara Research Center, Genetic Engineering and Biotechnology Institute, Kocaeli, Turkey. ${ }^{5}$ Arthritis \& Clinical Immunology Research Program, Oklahoma Medical Research Foundation, Oklahoma, USA. ${ }^{6}$ Departament de Medicina i Cirurgia Animals, Universitat Autònoma de Barcelona, 08193 Bellaterra, Barcelona, Spain. ${ }^{7}$ Department of Pharmacology, Uludag University School of Medicine, Bursa, Turkey. ${ }^{8}$ Interdisciplinary Laboratory of Clinical Analysis, Interlab-UMU, Regional Campus of International Excellence "Campus Mare Nostrum", University of Murcia, Espinardo, Murcia 30100 , Spain. ${ }^{9}$ Department of Pharmacology, Acibadem University School of Medicine, Istanbul, Turkey.

Received: 10 February 2016 Accepted: 10 September 2016 Published online: 20 September 2016

\section{References}

1. Morris DD. Endotoxemia in horses: a review of cellular and humoral mediators involved in its pathogenesis. J Vet Inter Med. 1991;5:167-81. 
2. Adams JL, Semrad SD, Czuprynskil CJ. Administration of bacterial lipopolysaccharide elicits circulating Tumor necrosis factor-alpha in neonatal calves. J Clin Microb. 1990;8:998-1001.

3. Bistrian BR. Acute phase proteins and the systemic inflammatory response. Crit Care Med. 1999;27:452-3.

4. IIcol YO, Yilmaz Z, Ulus $\mid H$. Endotoxin alters serum free choline and phospholipid-bound choline concentrations and choline administration attenuates endotoxin-induced organ injury in dog. Shock. 2005;24:288-93.

5. IIcol YO, Yilmaz Z, Cansev M, Ulus IH. Choline or CDP-choline alters serum lipid responses to endotoxin in dogs and rats: involvement of the peripheral nicotinic acetylcholine receptors. Shock. 2009;32:286-94.

6. Yilmaz Z, Il coL YO, Torun $\mathrm{S}$, Ulus $\mathrm{H}$. Intravenous administration of choline or CDP-choline improves platelet count and platelet closure times in endotoxin-treated dogs. Shock. 2006;25:73-9.

7. Yilmaz Z, Ozarda Y, Cansev M, Eralp O, Kocaturk M, Ulus IH. Choline or CDPcholine attenuates coagulation abnormalities and prevents the development of acute disseminated intravascular coagulation in dogs during endotoxemia. Blood Coagul Fibrin. 2010;21:339-48.

8. Parrish WR, Rosas-Ballina M, Gallowitsch-Puerta Ochani M, Ochani K, Yang L, et al. Modulation of TNF release by choline requires alpha7 subunit nicotinic acetylcholinemediated signaling. Mol Med. 2008;14:567-74.

9. IIcol YO, Gurun MS, Taga Y, Ulus $\|_{\text {. }}$. Choline increases serum insulin in rat when injected intraperitoneally and augments basal and stimulated acetylcholine release from the rat minced pancreas in vitro. Eur J Biochem. 2003;270:991-9.

10. Cao Z, Robinson RA. The role of proteomics in understanding biological mechanisms of sepsis. Proteomics-Clin Appl. 2014;8:35-52.

11. Soares AJ, Santos MF, Trugilho MR, Neves-Ferreira AG, Perales J, Domont GB. Differential proteomics of the plasma of individuals with sepsis caused by Acinetobacter baumannii. J Proteomics. 2009;73:267-78.

12. Stewart CJ, Nelson A, Treumann A, Skeath T, Cummings SP, Embleton ND, Berrington JE: Metabolomic and proteomic analysis of serum from preterm infants with necrotising entercolitis and late onset sepsis. Ped Res 2015, doi: 10.1038/pr.2015.235. (Epub ahead of print).

13. Ceciliani F, Eckersall D, Burchmore $R$, Lecchi C. Proteomics in veterinary medicine: applications and trends in disease pathogenesis and diagnostics. Vet Pathol. 2014;5:351-62.

14. Camprubí-Rimblas M, Artigas A, Guillamat-Prats R. An overview of proteomics on sepsis. J Phys Chem Biophys. 2015;5:183-9.

15. Semrad SD. Comparative efficacy of flunixin, ketoprofen, and ketorolac for treating endotoxemic neonatal calves. Am J Vet Res. 1993;54:1511-6.

16. Gerros TC, Semrad SD, Proctor RA, LaBorde A. Effect of dose and method of administration of endotoxin on cell mediator release in neonatal calves. Am J Vet Res. 1993;54:2121-7.

17. Coskun A, Sen I. Acute phase response and clinical changes in calves with lipopolysaccharide induced endotoxemia. Eurasian J Vet Sci. 2012;28:21-6.

18. Haçarız O, Sayers G, Baykal AT. A proteomic approach to investigate the distribution and abundance of surface and internal Fasciola hepatica proteins during the chronic stage of natural liver fluke infection in cattle. J Proteome Res. 2012;11:3592-604.

19. Haçarız O, Baykal AT, Akgün M, Kavak P, Sağıroğlu MȘ, Sayers GP. Generating a detailed protein profile of Fasciola hepatica during the chronic stage of infection in cattle. Proteomics. 2014;14:1519-30.

20. Haçarız O, Baykal AT. Investigation of the abundance of proteins secreted by Fasciola hepatica, which is exposed to environmental change inexperimental studies, with an advanced proteomic approach. Turkiye Parazitol Derg. 2014:38:106-10.

21. Calvano SE, Coyle SM. Experimental human endotoxemia: a model of the systemic inflammatory response syndrome? Surg Infect (Larchmt). 2012;13:293-9.

22. Scheffler JM, Sparber F, Tripp CH, Herrmann C, Humenberger A, Blitz J, Romani N, Stoitzner $P$, Huber LA. LAMTOR2 regulates dendritic cell homeostasis through FLT3-dependent mTOR signalling. Nat Commun. 2014;5:5138.

23. Fukaya $Y$, Shimada H, Wang LC, Zandi E, DeClerck YA. Identification of galectin-3-binding protein as a factor secreted by tumor cells that stimulates interleukin- 6 expression in the bone marrow stroma. J Biol Chem. 2008;283:18573-81.

24. DeRoo EP, Wrobleski SK, Shea EM, Al-Khalil RK, Hawley AE, Henke PK, Myers Jr DD, Wakefield TW, Diaz JA. The role of galectin-3 and galectin-3-binding protein in venous thrombosis. Blood. 2015;125:1813-21.
25. Lin TW, Chang HT, Chen CH, Chen CH, Lin SW, Hsu TL, Wong CH. Galectin-3 binding protein and galectin-1 interaction in breast cancer cell aggregation and metastasis. J Am Chem Soc. 2015;137:9685-93.

26. Kim Jl, Ho IC, Grusby MJ, Glimcher LH. The transcription factor c-Maf controls the production of interleukin-4 but Not other Th2 cytokines. Immunity. 1999;10(6):745-51.

27. Nenke MA, Rankin W, Chapman MJ, Stevens NE, Diener KR, Hayball JD, Lewis JG, Torpy DJ. Depletion of high-affinity corticosteroid-binding globulin corresponds to illness severity in sepsis and septic shock; clinical implications. Clin Endocrinol (Oxf). 2015;82:801-7.

28. Lim YP, Bendelja K, Opal SM, Siryaporn E, Hixson DC, Palardy JE. Correlation between mortality and the levels of inter-alpha inhibitors in the plasma of patients with severe sepsis. J Infect Dis. 2003;188:919-26.

29. Fries E, Kaczmarczyk A. Inter-alpha-inhibitor, hyaluronan and inflammation. Acta Biochim Pol. 2003:50:735-42.

30. Tvarijonaviciute A, Kocaturk M, Cansev M, Tecles F, Ceron JJ, Yilmaz Z Serum butyrylcholinesterase and paraoxonase 1 in a canine model of endotoxemia: effects of choline administration. Res Vet Sci. 2012;93:668-74.

31. Xu J, Zhang X, Pelayo R, Monestier M, Ammollo CT, Semeraro F, Taylor FB, Esmon NL, Lupu F, Esmon CT. Extracellular histones are major mediators of death in sepsis. Nat Med. 2009;15:1318-21.

32. Tolosano E, Altruda F. Hemopexin: structure, function, and regulation DNA. J Cell Biol. 2002;21(4):297-306.

33. Schaer DJ, Vinchi F, Ingoglia G, Tolosano E, Buehler PW. Haptoglobin, hemopexin, and related defense pathways — basic science, clinical perspectives, and drug development. Front Phys. 2014;5:415.

34. Janz DR, Bastarache JA, Sills G, Wickersham N, May AK, Bernard GR, Ware LB. Association between haptoglobin, hemopexin and mortality in adults with sepsis. Crit Care. 2013;17:R272.

35. Shainkin-Kestenbaum R, Zimlichman S, Lis M, Lidor C, Pomerantz M, Knyszynski A, Preciado-Patt L, Fridkin M: Effect of serum amyloid A, HDL apolipoprotein, on endothelial cell proliferation. Implication of an enigmatic protein to atherosclerosis. Biomed Pep Prot Nuc Acids 1996-1997, 2: 79-84.

36. Yamada T, Miyake N, Itoh $\mathrm{K}$, Igari J. Further characterization of serum amyloid A4 as a minor acute phase reactant and a possible nutritional marker. Clin Chem LabMed. 2001;39:7-10.

37. Rudiger A, Singer M. Mechanisms of sepsis-induced cardiac dysfunction. Crit Care Med. 2007:35:1599-608.

38. Peek SF, Apple FS, Murakami MA, Crump PM, Semrad SD. Cardiac isoenzymes in healthy Holstein calves and calves with experimentally induced endotoxemia. Can J Vet Res. 2008;72(4):356-61.

39. Amid A, Samah NA, Yusof F. Identification of troponin I and actin, alpha cardiac muscle 1 as potential biomarkers for hearts of electrically stimulated chickens. Proteome Sci. 2012:10:1.

40. Frade AF, Teixeira PC, lanni BM, Pissetti CW, Saba B, Wang LHT, et al. Polymorphism in the alpha cardiac muscle actin 1 gene is associated to susceptibility to chronic inflammatory cardiomyopathy. PLoS One. 2013;8:e83446.

41. Haoyuan W, Shanshan J, Yaojun Z, Ke P, Jianchuan X, Minshan C. High expression of thymosin beta 10 predicts poor prognosis for hepatocellular carcinoma after hepatectomy. World J Surg Oncol. 2014;12:226.

\section{Submit your next manuscript to BioMed Central and we will help you at every step:}

- We accept pre-submission inquiries

- Our selector tool helps you to find the most relevant journal

- We provide round the clock customer support

- Convenient online submission

- Thorough peer review

- Inclusion in PubMed and all major indexing services

- Maximum visibility for your research

Submit your manuscript at www.biomedcentral.com/submit 